\title{
Causes of Irregular Migration, Institutional and Legal Responses, Political Crisis in Ethiopia and the Measures Taken by the Laureates Noble Peace Winner Abiy Ahmed
}

\author{
Gutema Adem ${ }^{1}$, Idris Ebrahim ${ }^{2}$ \\ ${ }^{1}$ Department of Civics and Ethical Studies, College of Social Science and Humanities, Madda Walabu University, Robe, Ethiopia \\ ${ }^{2}$ Department of Sociology, College of Social Science and Humanities, Madda Walabu University, Robe, Ethiopia
}

Email address:

gutemaadem81@gmail.com (G. Adem),daandiiidris30@gmail.com (I. Ebrahim)

\section{To cite this article:}

Gutema Adem, Idris Ebrahim. Causes of Irregular Migration, Institutional and Legal Responses, Political Crisis in Ethiopia and the Measures Taken by the Laureates Noble Peace Winner Abiy Ahmed. English Language, Literature \& Culture. Vol. 5, No. 4, 2020 , pp. $124-131$. doi: $10.11648 /$ j.ellc.20200504.11

Received: August 3, 2020; Accepted: August 24, 2020; Published: November 23, 2020

\begin{abstract}
This article examined the fundamental causes of irregular migration in Ethiopia and the legal and institutional response of the government against human trafficking and smuggling. The data used in this articles are collected from the purposely selected return irregular migrants, activists, members of political parties and secondary data sources are collected from books, laws, and researchers' personal observation. Legal as well as socio-legal method was applied in analyzing the data collected. Though the world are in the era of irregular migration, migration is not simply situation of safe paradise without any risk to states, global communities and to human security and dignity of migrants. Accordingly the fundamental causes of irregular migration in Ethiopia are diverse, structural and inter locked. Poverty, unemployment, political crisis, social network connection, poorly enforcement of the existing law and legal gap, violation of democratic rights, corruption, unlawful arrest and detention, biased and partisan administrative, discriminatory service provision and unfair judicial system are taken as the principal driving factors for irregular migration in Ethiopia. As result of the aforementioned factors, Ethiopia the cradle of human being, today named as cradle for human trafficking and smuggling pursuing profit seeking and cheap labour for inexpensive and convenient servitude. Thus, correcting this disparity of structural and social injustice in Ethiopia is central to tackling poverty and inequality. To reduce the threat of shocks as result of poverty, individuals and governments must seek to enhance people's security: not the militarized version of security that has dominated public debate in recent two years under the regime of Ethiopian primister Abiy Ahmed, but a more comprehensive human version, taking the insecurity and anxiety ridden experience of living in poverty as its starting point. Thus, the researcher recommended that guaranteeing security in this way means strengthens poor, humiliated and dissatisfied Ethiopian ability to survive shocks and increases their chances of escaping $g$ from poverty in general, and irregular migration in particular.
\end{abstract}

Keywords: Irregular Migration, Causes, Legal and Institutional Responses, Political Crisis and Neo-Naftegna

\section{Introduction}

It is important to know why some people leave their place of residence or move and others do not. However the forces driving migration are varied and complex, and global explanations may not apply to all individual situations. Poverty, wars, famine and repression are certainly among the major causes of migration, but there are other factors as well. Some of the reasons for Trans borders migration include population pressures on scarce natural resources, income inequality between poor and rich countries, the growing of urbanization, political crisis and instability, reduction in the cost of transport and communications, the absence of respect for human rights in some countries and establishment of migration networks by earlier migrants [9].

Migration is an economic, social and political process that affects those who move, who stay behind, and the place where they go. International labour migration has emerged as a major global issue that affects most nations in the world and takes high value on the international, regional and 
national policy agendas. Through their labour, migrants contribute a lot for growth and development in their countries. Yet the migration process pose serious challenges to migrants. Many migrant workers, especially low skilled workers face exploitative working conditions and enjoy limited human and lab our rights (Ibid). In these situations the rights that migrants entitled are in danger.

Population mobility in and from the Horn of Africa has a long standing tradition. However, conflict, environmental deterioration and economic decline coupled with growing economically active populations have increased labour and forced migration both in the region and beyond. These migration flows are generally of a heterogeneous nature, comprising traditional trans-border mobility, labour migration, asylum migration and irregular migration. Thus, population growth in sub-Saharan has increased the force of people in recent decades.

Castles and Miller [3] have labeled the current era the as the age of migration arguing that there is both an unprecedented volume of international migration and a global reach of international migration that is affecting more countries than ever before. De Haas argues that the number of people migrating internationally has not increased, rather the percentage of the population international migrants has stayed relatively stable but the direction of flows has changed, with the post-world war the second era seeing previously unprecedented south-north migration movements.

Three factors must be present for migration to take place: demand or pull from destination countries; supply or push from states or countries of origin; and networks to link the supply with the demand. Networks are often family or community-based, although labour recruiters may also stimulate movements. Migrants tend to go to places in which their relatives, friends and community members are already located [21].

A number of factors have contributed to the increase in international migration, including the following:

1) Economic globalization-which linked the economies of origin and destination countries together-led to trade agreements that contain provisions for mobility of international personnel, goods and services, prompting the growth of multinational corporations that move their personnel between countries and across the globe;

2) Demographic trends, with many developed countries facing population stagnation and ageing while developing countries continue to grow faster than their job markets can absorb new workers;

3) The transportation revolution that has made migration affordable to millions of would-be migrants;

4) The revolution in communications (internet, cellular phones) that informs would-be migrants of opportunities outside their home countries and allows them to keep in touch with families and communities left behind;

5) The growth in transnational communities with growing numbers of persons with dual or multiple nationalities and citizenship who remain involved in the countries of their origin as well as their countries of destination.

International migration from Ethiopia is an economic coping strategy and a societal issue. The migration of a family member generates resources, which support other family members and enables them to make investments in education, health and housing. The ability to invest in these resources reduces the vulnerability of family members, particularly women and children. Migration is also a means to improve the family's social status: providing their younger sibling with better education opportunities is a very strong incentive for Ethiopians to migrate abroad.

\section{Irregular Migration in Ethiopia}

Koser [11] argue that the reason that the increasing in the number of migrants moving in an illegal ways than legal ways is mainly because of increasing restrictions on legal movements, especially in the host countries.

As far as irregular migration is a global phenomenon Ethiopia cannot escape this chronic problem. The concept irregular migration is a complex and diverse that requires thoughtful clarification. However, Irregular migration used in this article is to mean only those people who enter a country without the proper authority (for example through clandestine entry and entry with fraudulent documents. It is usual to hear the discourses of migration crisis from the local media, Mainstream mass media and from public discussion of day today. The research conducted by Beydoun (2006), found out that; poverty, lack of viable employment and desperation created fertile ground for the trafficking and migration of Ethiopian to abroad. Ethiopia, the cradle of mankind, today serves as cradle for traffickers pursuing profit seeking and cheap labour -for inexpensive and convenient servitude.

The phenomenon of exploitation, oppression, human right abuse like forced rape, prostitutions, ruthless mass killing in Libya [12], xenophobic attack in south Africa, massive deportation of Ethiopian irregular migrant from Saudi Arabia (US state department 2015), hundreds of government sponsored returnees from Yemen, Lebanon and the threat of ISIS, political crisis in the host states are the few problems the Ethiopian migrant are facing.

According to the recent study by the regional mixed migration secretariat [18], Ethiopian migrant to abroad uses three main channel for migration. These are public migration that are facilitated by Ethiopian minster of labour and social affairs (MoLSA), through legally registered private employment agencies (PEAs) and finally irregular migration using the services of illegal agents and brokers [10].

Especially in the year 2014 and 2015, Irregular migration crisis in Ethiopia is worryingly become severe and miserable occupying the concern of academic researcher, policy maker and the public at large. For instance, only in the year 2014, it is recorded that more than 800,000 irregular migrants entered Europe though the Mediterranean see and around 4077 died of which majority of them are by crossing Mediterranean see [13].

Socio Economic Factors As causes of Migration in Ethiopia 


\section{Poverty and unemployment}

Poverty is characterized by inadequacy or lack of productive means to fulfill basic needs such as food, water, shelter, education, health and nutrition. The multidimensional character of poverty in Ethiopia is reflected in many respects, such as destitution of assets, vulnerability and human development. The World Banks definition of poverty indicates that poverty is “... a marked deprivation of wellbeing related to lack of material income or consumption, low levels of education and health, vulnerability and exposure to risk and voicelessness and powerlessness [15].

Understanding poverty in the Ethiopian context needs to consider its multidimensional characteristics which go beyond mere income and food provision. Such characteristics includes aspects of human capabilities, assets and activities necessary for sustainable livelihoods. A sustainable livelihood is one that can cope with and recover from stresses and shocks and maintain or enhance its capabilities and assets both now and in the future, without undermining the natural resource base [2].

The fundamental causes of migration in general and irregular migration in particular are diverse, complex and interlocked with various social economic and, political issues [10]. The existing backwardness and the resulted poverty, highest unemployment and political crisis remain as the primary causes for irregular migration in Ethiopia. According to the 2015 UNDP report of human of human development index (HDI) Ethiopia is ranked at $174^{\text {th }}$ out of 188 countries [20]. With the same talk the report of the World Bank categorized Ethiopia as one of the poorest countries in the world of which $29.6 \%$ population are under poverty line [14]. Development is about transforming the lives and expectations of a nation's inhabitants, an ambition that goes far beyond simply increasing monetary income. Although the past 2 years have seen enormous progress in Ethiopia under the reformist government of Ethiopia led by laureate colonel Abiy Ahmed the 2019 Noble peace prize winner, huge and urgent challenges remain in tackling injustice, inequality, political crisis and political assassination, ethnic conflict, desert locust, corona virus (covd-19 and dis agreement among Ethiopian, Sudan and Egypt over grand Ethiopian renascence damp and the interference of world bank and international monetary fund as negotiators of grand Ethiopian renascence damp but standing on the behalf Egyptian and the opposition, peaceful demonstration and remittance boycott by Oromo and other Ethiopian diaspora are dramatically testing the reformist government in generally and the Ethiopian economy in particular. The starting point for this effort must be guaranteeing that all people enjoy their basic rights and the ability to exercise capabilities. People living in poverty must take or create power over their own lives and destinies. To develop and democratized, country need educated, informed, and healthy citizens and a state both willing and able to provide the essential services on which their well-being depends. The state must also ensure that both the quality and quantity of economic growth meets developmental needs.
The government rhetoric with regards to poverty comes out of a tradition in which exploitative structures have been seen as the major cause of poverty. 'By supporting a social hierarchy that was markedly extractive and exploitative, Ethiopian population lived for many years in a terrible state of ignorance and gruesome conditions of deprivation and poverty' [7]. It is undeniable fact that much more is known about the economic aspects of poverty in Ethiopia, it has become clear to many in the development field that exploitative relationships, and the processes of social exclusion and conflict, political crisis are major causes of poverty in many contexts that need investigation. Society, economy, politics and culture in Ethiopia are in the cross road of long-term structural change which must be understood for effective policy and actions to guide that change in pro-poor directions and to skyrocket the country from extremely absolute poverty.

By all accounts Ethiopia ranks among the poorest countries worldwide according to standard for international indicators for income, health, and education. Ethiopia falls among the poorest countries globally, within the least developed countries and in sub Saharan Africa (SSA). According to the Trufat, Bekele [19]. Ethiopia is one of the least developed countries in terms of GNP per capita life expectancy below the world average, infant mortality is almost double the world average and the adult literacy rate is less than half of the world rate. In the country the status and the availability of infrastructure like road and, transport, communication, market, etc., is very poor. Public utilities such as electricity and water, are unavailable for significant portion of the population.

Thus, correcting that disparity of structural and social injustice in Ethiopia is central to tackling poverty and inequality. To reduce the threat of shocks as result of poverty, individuals and governments must seek to enhance people's security: not the militarized version of security that has dominated public debate in recent years, but a more comprehensive human version, taking the insecure and anxiety ridden experience of living in poverty as its starting point. Guaranteeing security in this way means strengthens poor people's ability to survive shocks and increases their chances of escaping $g$ from poverty, and not falling back.

Political factors

The RMMS [18] political factors such as in ability to exercise fundamental rights and freedoms, violation of democratic rights, corruption, unlawful arrest and detention especially in Oromiya regional state, biased and partisan administrative, discriminatory service provision and unfair judicial system are taken as the principal driving factors for irregular migration in Ethiopia.

The key elements in political transformation are political pluralism and decentralization of power based on ethnic linguistic criterion. However, Ethiopian state remained authoritarian and oppressive [17]. There are several drawbacks in an attempt to transform and democratize the Ethiopian state. To mention few of them:

1) Human and civil rights were enshrined in the federal 
democratic republic of Ethiopian constitution, but there are well recorded violation of human right in Ethiopia, especially in southern and western Oromiya, Amhara, Benshangul Gumuz, Sidama and Political assassination of prominent Oromo singer and human right activist Haaccalu Hundessa on June, $30 / 2020$ at the Capital city Finfine (Addis Ababa).

2) Civil organization and independent press are allowed, but they are working under very unjustified condition, while some of them are closed such as: OMN (Oromiya media network, ONN (Oromiya news network and OBS (Oromiya broadcasting services.

3) The right of association and multi-party system are constitutionally guaranteed, but some parties are declared illegal, leaders of OFCs (Oromo federalist Congress and the prominent human right activist, politician and leaders of Oromo Qeerroo (youth) and founder of Oromiya Media network Jawar Mohammed, and Bekele Garba deputy leader OFC and, Hamza Borana members OFC are jailed and while those that are allowed to operate are under a serious pressure.

4) There are constitutionally recognized rights for ethnic groups and decentralization of power, but the reality in the ground is too far from what is practically happening. The existing reality on the ground is new ethnocratic state under the command of Neo-Naftegna (those who aspire the king centralist and unitary ideology).

5) The hidden agenda of the philosophy of Madamer (Synergy) articulated by the terrorist laureates of Noble peace prize winner Colonel Abiy Ahmed against ethnic based federalism (ethno-linguistic federalism of Ethiopia.

6) The consideration of article 39 (1) of Federal Democratic Republic of Constitution (Every Nation, Nationality and People in Ethiopia has an unconditional right to self-determination, including the right to secession as a threat to Ethiopia unity by neonaftegna and the centralist elite.

7) The tension between the Federal government and the TPLF (Tigray liberation front, the former politically dominant groups in Ethiopia for the last 27 years.

8) The historical and constitutional ownership questions of Oromo people over the Finfine (Addis Ababa and the silence of the reformist government for the questions. The special interest of the State of Oromiya in Addis Ababa, regarding the provision of social services or the utilization of natural resources and other similar matters, as well as joint administrative matters arising from the location of Addis Ababa within the State of Oromiya, shall be respected (EDREC, 1995 article 49 (5). It was the Qeerroo revolution under the leadership of Jawar Mohammed that fired from west shewa (Ginci) in 2014 against Addis Ababa master plan ended the dominance of Tigray liberation front in the year 2018. Unfortunately, the illusionist colonel Abiy Ahmed come to power promising the questions of
Oromo and Qeerroo will get constitutional answer yet, the Qeerroo revolution and the promised oath hijacked by Neo-naftegna groups without achieving the intended goal.

9) The betrayal of genocide conducted against the Oromo nation in the $19^{\text {th }}$ century by internal colonizer and assimilationist emperor Menelik II, and the removal of Anole and Calanqo history from education curriculum by the existing regime.

10)The assassination and murder of Oromo students at Ahmara National regional states by Neo naftegna groups, and the burning of religious institutions (mosques) in 2019 with the slogan of we will restore and repeat the history of our grandfather, i.e. Menelik II and emperor Hailesellaisie.

11)The 1995 Federal Democratic Republic of Ethiopian Constitution gives free, fair and periodic election to citizens, but the Ethiopian government led by Abiy Ahmed postponed the six round national election for unknown time un constitutionally by the pre text of corona virus (covd-19). As a result, this government loss constitutional legitimacy from October 2013 and become gangster politician. Due to the failure of timely political crisis the government structure is already broken, there is no elected government organ to solve the problems of the people.

12)The Slicing of the mass revolution un constitutional by declaring state of emergency, using the gun, and firing out of government employer from its work by the pre text of you are the member of opponent political parties are few of them.

13)Article 35 [4] federal democratic republic of Ethiopian constitution state that the State shall enforce the right of women to eliminate the influences of harmful customs. Laws, customs and practices that oppress or cause bodily or mental harm to Women are prohibited. However, the rights of women and children are vulnerable, gender based violence, female genital mutilation, abduction and forced rape by government military are common and support for survivors is inadequate.

14)The right to equality between men and women in marriage and family Life is also recognized in in federal democratic republic of Ethiopian constitutions and various human rights instruments, including the Universal Declaration of Human Rights, the International Covenant on Civil and Political Rights, the Convention on the Elimination of All Forms Of Discrimination against Women, the Convention on the Nationality of Married Women, and the Convention on Consent to Marriage, Minimum Age for Marriage and Registration of Marriages. Women nevertheless lag behind men in the enjoyment of rights related to the private sphere. For instance article 34[1] of Federal Democratic Republic of Ethiopian Constitution state that men and women, who have attained marriageable age as defined by law, have the right to marry and 
found a family. Furthermore, it is clearly stated that both women and men have equal rights while entering into, during marriage and at the time of divorce and article 34 [2] ensures that marriage should be entered into only with the free and full consent of the intending spouses but given the traditional environment in which women have little or no rights in deciding on such matters, it is difficult, if not impossible, for women to realize and enjoy these rights. Article 34 [4 and 5] FDRE constitution extends recognition to marriage concluded under systems of religious or customary laws and it does not exclude the customary or religious adjudication of disputes relating to personal and family laws, with the consent of the parties to dispute. This recognition is a potential threat that perpetuates the existing gender inequalities in the society. Because, intentionally or unintentionally, these laws usually work in the way that sustain and maintain the subordination of women and girls[18]

15)In null sheet extra judicial detention and mass killing sponsored by the Ethiopian terrorist state are frequent occurrences in the countries. The executive branch under the omnipotent control of Ethiopian prosperity party (pp) complicated the political crisis in Ethiopian and creative fertile ground for irregular migration in general and political migration of their citizen from the country in particular in the year 2019 and 2020. Terrorism by the state involves deliberate coercion and directed at some victim, with the intention of inducing extreme fear in some target observers who identify with that victim in such a way that they perceive themselves as potential future victims. In this way they are forced to consider altering their behavior in some manner desired by the actor [19].

The Ethiopian government routinely denies charges of serious human rights violations and has regularly sought to identify the victims and witnesses providing information published in human rights reports. The authorities have harassed and detained individuals for providing information to, or meeting with, international human rights investigators, journalists (Oromiya media network Oromiya news network, Asrat media journalist, researchers and others among few of them. As a result it is extremely difficult to assure the safety and confidentiality of victims of human rights abuses in Ethiopia. Ethiopian private media journalists, bloggers, activists and other individuals are significantly faced human in security and protection challenges under the existing regime.

History tell us that Totalitarian regimes including those of Stalin ,Hitler Pol Pot, and the current a noble peace prize winner of 2019 of Ethiopian primister have used violence to terrorize populations into submitting with the regime's demands and attempt to establish and maintain their empires, and attempt to frustrate freedom movements in the country. Torture and ill-treatment have been used by Ethiopia's police, security forces, and even by militia at the local and inaccessible areas of Oromiya regional states. In fact the federal democratic republic of Ethiopian constitution prohibits such practices, but there are abuses against detainees by security officials. The frequency, severity, and patterns of abuse by agents of the central and state governments demonstrate systematic mistreatment involving elimination and disappearance of popular activists and politicians. Thus, we can conclude that the state of Ethiopia under the leadership of primister Abiy Ahmed are steadily moving towards the direction of state failures[20] defines state failure as the basic functions of the state are no longer performed. There are a numbers of indicators that shows this facts in Ethiopia. Some of them are: disharmony between communities, inability to manage and govern the regions and the entirety of the territory, a growth of criminal violence, political trial, corrupt institutions, injustice and inequality and a widespread poverty, heavy dependence on foreign aid, problematic programs by international institutions such as the IMF or the IBRD, decaying infrastructure, weak coordination between federal and regional government e.g. dis harmony Tigray regional state and federal government, increasing of human trafficking and smuggling and, murder and rape by government security force.

Generally failed states are characterized by:

1) A loss of control over borders

2) Rising ethnic-, religious-, linguistic- and cultural hostilities

3) Civil war

4) The use of terror against own citizens

5) Weak institutions

6) A deteriorated or insufficient infrastructure

7) An inability to collect taxes without undue coercion

8) A collapsed health system

9) Rising levels of infant mortality and declining life expectancy

10)The end of regular schooling opportunities

11)Declining levels of GDP per capita (especially inflation)

12)A widespread preference for non-national currencies

13)Basic food shortages - leading to starvation

14)Leaders destroy the economic and political fabric of the country

15)Questionable legitimacy [21].

In the political sphere, Ethiopian lacked, legitimate governing institutions that provide effective administration, ensure checks on power, protect basic rights and freedoms, hold leaders accountable, deliver impartial justice, and permit broad citizen participation. Moreover, the current political crisis of Ethiopia are very complex and interlocked. Thus, tackling such complex and interwoven politics under the rotten and outdated political culture is very difficult.

Social Network Causes of Migration/Culture of Migration

Though poverty, unemployment political crisis and demand for high wages caused people to move for migration; migrant network spread also equally contributed for their trans-border migration. This is strongly associated with family and peer pressure to migration. The society strong perception towards migration is one of the fundamental 
contribution factors. There was serious pressure on youngster to cross border by their families, peers and communities at large [18]. This was partly influenced by the success stories of other few migrants (MoLSA).

The migration of friends or family members is a key driving factors for migration and contributes to the development of a culture of migration. The migration of one member of group or friends or family often leads to the migration of other members from that group. The first migrant put pressure on others by sending remittances to parents.

Thus, the existing wrong and unrealistic story by prior migrated peoples and the consideration of migration as the only option to escape from the vicious circle of poverty leads the society to develop the culture of migration which consequently intensified trans-border migration irrespective of the risk associated with irregular migration (Gutema, 2013), presented the role of social network in migration accordingly; it is through the network that information is disseminated, contacts are established, employment opportunities for the new emigrants are created and social supports are provided.

Ethiopia domestic workers in the Middle East countries faces exploitative and forced confinement and in human treatment for two reasons. One is using the sponsorship (kafala) system as instrument to control including the personal life migrant worker such as sanction against the movement, restriction on information contact with parents at home. The second is to prohibit the migrant workers, if they will miss, just in order to escape from exploitation in the hands of employers [5].

The following Diagram shows extreme personal security risk that an irregular migrants faces during transit points and in the destination countries.

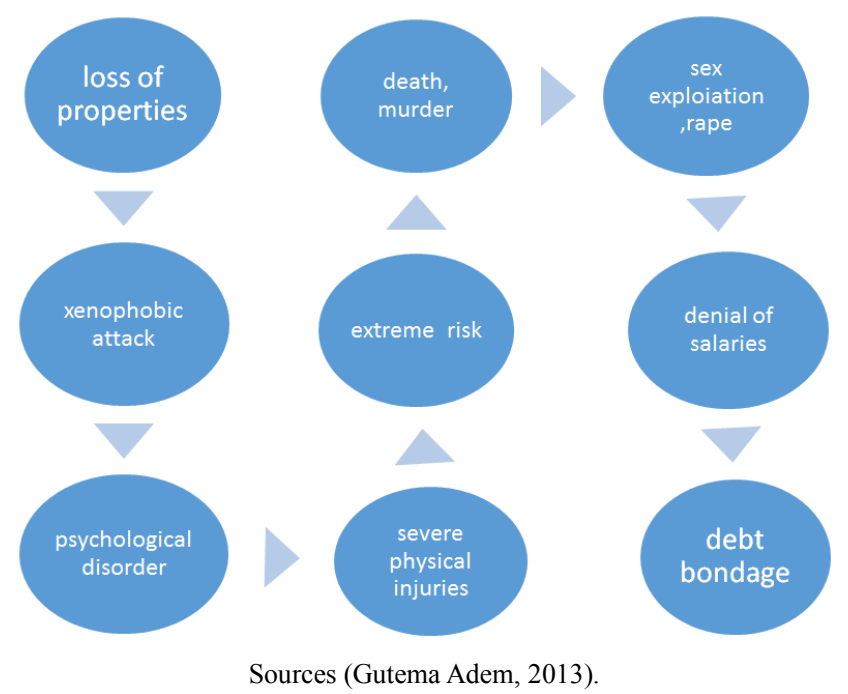

Figure 1. Extreme personality security risk irregular migrants face during transit point.

Irregular migrants live and work in unwarranted and dangerous jobs; they are excluded from health, education and other social welfare provisions, and they can be subject to exploitation, harassment and violence. The following figure show Ethiopian irregular migrants jailed in Saudi Arabia.

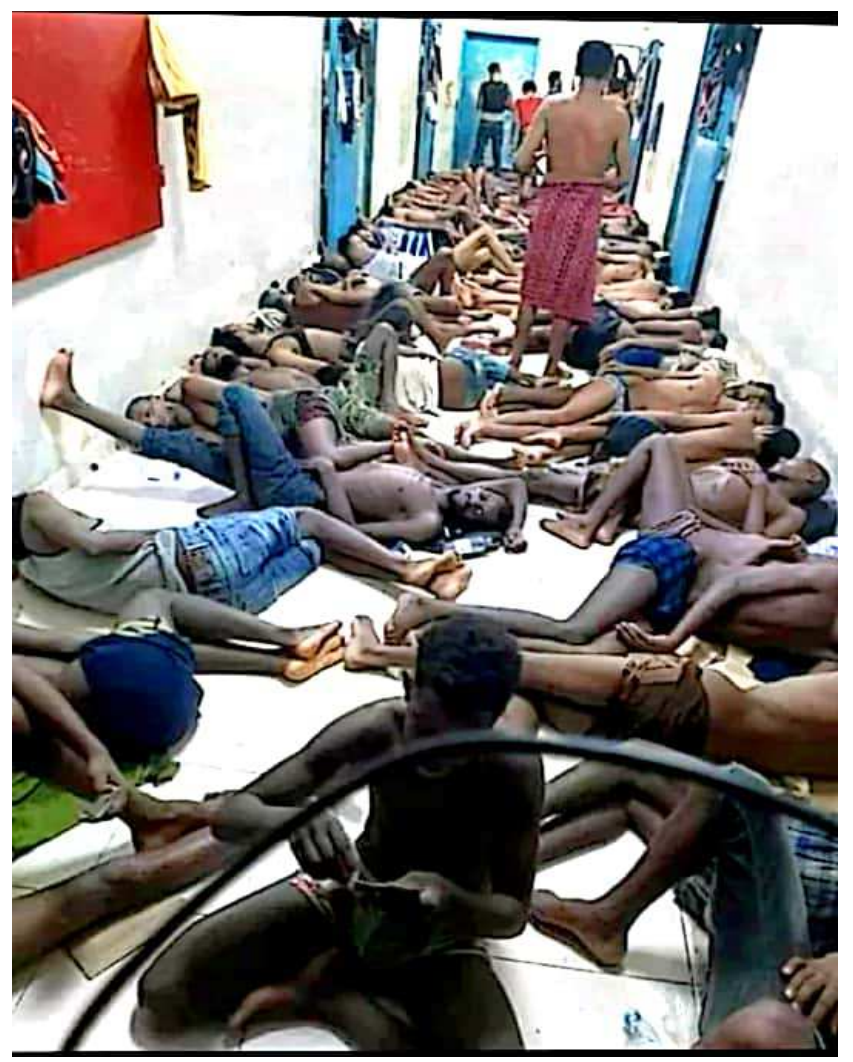

Figure 2. Source [photo sent to the researcher by jailed irregular migrant from Saudi Arabia 2020].

\section{The Legal and Institutional Response Against Irregular Migration}

Both at national level and global level the legal framework, the legal frame work gaps are relatively filled with the specific prevention and suppression of trafficking in person and smuggling of migrants. At international level convection enacted to prevent and suppress the 2000, UN convection against transnational organized crime with its two supplementary protocols (protocols against smuggling of migrants by land, sea and air and protocol to prevent suppress and punish trafficking in person is adopted [4]. Ethiopia is now state party to most of the specific convection targeting to prevention and suppression of trafficking in person and migrant smuggling.

The currently an increasing of seriousness of the issue in bringing grave violation of human rights, grief suffering of citizen, forced the Ethiopian government to enact anti trafficking and smuggling proclamation [16]. After prolonged period of legal frame work gaps, recently Ethiopia has introduced comprehensive national law specifically targeting to the prevention, suppression of trafficking in person and migrant smuggling. Moreover, besides the anti-trafficking and smuggling proclamation another existing national provision such as article 18 (2) 
of Federal democratic republic constitution are a key provision to which served to prevent and prosecute the issue before the enactment of new law. For instance the FDREC article 18 (2) [6], state that," no one shall be held in slavery and servitude. However in august 17, 2015, a separate national anti-trafficking and smuggling law is introduced. The new proclamation comprises 50 articles by emphasizing on four major pillars. These are: prevention, prosecution, protection and partnership in the process of combating the crime trafficking in person and human smuggling.

The proclamation also established a detail provision for the mechanism of prevention, rehabilitation, and compensation of victims of trafficking in person and smuggling of migrants. It believed that the provision gives much emphasis in its provision to protection. The protection provision includes identify the victims, providing rescue assistance, repatriation or returning the victims found outside the Ethiopia, and providing compensation for loses which directly resulted by the crime. For instance, article 26 (2a) of the provision state that Victims shall be accorded the available health and social services, medical care, counseling and psychological advices with care on confidential basis with full respect of privacy.

In addition to the enactment of the new law Ethiopia established a national council against human trafficking called the task force. Moreover, the Ethiopian national intelligence and security services (NISS) is also the main government body which has the direct competence with issues related to migration

However, the report of US department of state criticize that despite, the government maintained anti-trafficking law enforcement efforts,... continued to focus wholly on transnational labor trafficking with less evidences of investigation, of sex prosecution of trafficking or internal labor trafficking (US state department, 2015). The provision of protection also criticized due to its in adequate assistance and exclusive reliance on international organization and NGOs to provide services for the victims without providing funding to these organizations, most of the assistance focused only on temporary services like food and water, temporary accommodation and transportation back to their village and limited consular services provided by the Ethiopian workers abroad are few of them.

\section{Conclusion}

As most studies come up with the causes of cross border migration, the present study article also found out the major causes of migration in Ethiopia and the legal and institutional responses of the Ethiopian government.

The key elements in political transformation are political pluralism and decentralization of power based on ethnic linguistic criterion. However, Ethiopian state remained authoritarian and oppressive.

Political factors such as in ability to exercise fundamental rights and freedoms, violation of democratic rights corruption, unlawful arrest and detention especially in Oromiya regional state, biased and partisan administrative, discriminatory service provision and unfair judicial system are taken as the principal driving factors for irregular migration in Ethiopia

The executive branch under the omnipotent control of Ethiopian prosperity party ( $p p)$ complicated the political crisis in Ethiopian and creative fertile ground for trans-border migration of their citizen from the country.

The currently an increasing of seriousness of the issue in bringing grave violation of human rights, grief suffering of citizen, forced the Ethiopian government to enact anti trafficking and smuggling proclamation [16]. After prolonged period of legal frame work gaps, recently Ethiopia has introduced comprehensive national law specifically targeting to the prevention suppression of trafficking in person and migrant smuggling.

However, the newly enacted law criticized due to its in adequate assistance and exclusive reliance on international organization and NGOs to provide services for the victims without providing funding to these organizations, most of the assistance focused only on temporary services like food and water, temporary accommodation and transportation back to their village and limited consular services provided by the Ethiopian workers abroad are few of them.

The discussion had revealed that the irregular migration of Ethiopian to broad aggravated as result of Poverty, political crisis, unemployment, the aspiration to support their family, network connection with former migrants and misinformation by certain brokers about work migration in other states are the major pressing factor behind their migration.

The finding of the article also revealed that, migrants are vulnerable to varies forms of working condition and abuse in the destination countries. Heavy work load, malnutrition, sexual abuse, and ill health treatments are few of them. Moreover, isolation due to separation from their family, racial discrimination that regards the black house maid's donkey, slave and communication difficulties to express their own opinions and restriction on the freedom of movements from the compound of the employer are some of them.

\section{Limitation of the Article}

The Ethiopian government restricts human rights research in the country, this research is not a comprehensive assessment of human right violation, human trafficking and political crisis situation in Ethiopia due to the human insecurity, punishment and fear of the researchers and data providers.

\section{References}

[1] Beydoum, (2006). The Trafficking of Ethiopian Domestic worker into Lebanon: Navigation through a Novel passage of International Maidtrade, 24 Berkeley J. Int'law.1009. 
[2] Carney, D. (1998). Implementing the Sustainable Livelihood Approach: Sustainable Rural Livelihoods: What Contribution can We Make? DFID. London, UK.

[3] Castels, and Miller, M. j. (2003). The Age of migration: International Population Movements in the Modern world. Basingstoke: Palgrave Macmillan.

[4] Elias, Ashene. (2013). Trafficking of Ethiopian women and girls to the Middle East. Master Thesis, Central European University.

[5] Endalamaw Chekol. (2016). International irregular Migration: Causes and its Impact on Human Security in Bale Oromiya. Madda Walabu University, Ethiopia.

[6] FDREC. (1995). Federal Democratic Republic of Ethiopian Constitution. Addis Ababa, Ethiopia.

[7] Gebru Tareke, (1991). Power and Protest: Peasant Revolts in the Twentieth Century Cambridge University Press, Gutema, Adem. (2013). Causes and Consequences of Female Migration to the Arab States: in Tena Woreda, Oromiya Region. MA Thesis, BahirDar University, Ethiopia.

[8] ] Gutema A., Sultan M., Idiris I (2020). Critical Analysis on the Causes and Consequences of Gender Based Violence and the Collapse of Siinqee and Attette institution of women in Oromiya Regional State of Ethiopia.. Int. J. Polit. Sci. Develop. 8(5) 184-190

[9] ICMPD. (2008). East Africa Migration Route, Initiative, Gap and Needs Analysis Project country Reports: Ethiopia, Kenya and Libya Vienna: Author.

[10] ILO. (2010). International labour Migration, Aright Based Approach. Geneva: Author.

[11] IOM. (2015). Trafficking lives lost during Migration. international Organization for Migration. Geneva, Switzerland.

[12] Koser, k. (2007). Irregular Migration: Avery short introduction. New York: oxford.
[13] Mehari, T. (2015). Migration Governance in Ethiopia: the need for Comprehensive National policy on Migration. the reporter-English edition.

[14] Metcalfe-Hough. (2015). the migration crisis? Facts, Challenges and Possible solutions. Overseas Development Institute.

[15] Naami, k. (2014). Female Ethiopian Migrant Domestic Workers: Analysis of Migration, Return Migration and Re integration Experiences. MA thesis unpublished.

[16] Pradham, (2002). Assessment of Policy Reduction Policies and Programs in India, a paper presented in a conference on: Assessment of Poverty Reduction Policies, organized by INSEA and IDRC, under Micro Impacts of Macro-economic Adjustment Policies (MIMAP) Project, January 28-31, 2002, Rabat, Moroco.

[17] Proclamation No. 909 (2015). "Prevention and suppression of Trafficking in Persons and Smuggling of Migrants". Federal Negrait Gazeta. Ethiopia, Addis Ababa.

[18] Professor Merara. (nd). Ethiopia: A Transition without Democratization. Addis Ababa University, Ethiopia.

[19] RMMS. (2014). The Letter of the law: Regular and Irregular Migration in Saudi Arabia in a Context of Rapid Change. Mixed Migration Research Series. RMMS, 4, 1-85.

[20] Rotberg, R.I.( 2002. Failed States in a World of Terror. Foreign Affairs, 81(4): 127- 140

[21] Trufat, Bekele (1999). Poverty and Policy in Ethiopia: Economic Reform and Gender (A Discussion Paper.

[22] UNDP. (2015). Briefing Notes for Countries on the 2015Human Development Reports. Ethiopia.

[23] United Nations (2006). 2004 World Survey on the Role of Women in Development: Women and International Migration. United nation, New York.

[24] Zartman, I.W. (ed.) Collapsed States: The Disintegration and Restoration of Legitimate Authority, Boulder, CO: Lynne Rienner, 1995. http://www.foreignpolicy.com 